\title{
Corporate communication through social networks: The identification of the key dimensions for dialogic communication
}

\author{
Paul Capriotti, \\ University Rovira $i$ Virgili (URV), Spain
}

Ileana Zeler, University of Girona (UdG), Spain

Mark Anthony Camilleri', University of Malta, Malta

https://orcid.org/0000-0003-1288-4256

This is a pre-publication version.

How to Cite: Capriotti, P., Zeler, I. \& Camilleri, M.A. (2020). Corporate communication through social networks: The identification of the key dimensions for dialogic communication. In Camilleri, M.A. (Ed.) Strategic Corporate Communication in the Digital Age, Emerald, Bingley, UK.

\begin{abstract}
Web 2.0 and the social networks have changed how organizations interact with their publics. They enable organizations to engage in symmetric dialogic communications with individuals. Various organizations are increasingly using different social media to enhance their visibility and relationships with their publics. They allow them to disseminate information, to participate, listen and actively engage in online conversations with different stakeholders. Some social networks have become a key instrument for corporate communication. Therefore, this chapter presents a critical review on the organizations' dialogic communications with the publics via social networks. It puts forward a conceptual framework that comprises five key dimensions including 'active presence', 'interactive attitude', 'interactive resources', 'responsiveness' and 'conversation'. This contribution examines each dimension and explains their effect on the organizations' dialogic communication with the publics. Hence, this contribution has resulted in important implications for corporate communication practitioners as well as for academia. Moreover, it opens future research avenues to academia.
\end{abstract}

Keywords: dialogic communication, corporate communication, online conversations, social media, social networks, online visibility, online responsiveness.

\footnotetext{
${ }^{1}$ Department of Corporate Communication, Faculty of Media and Knowledge Sciences, University of Malta, MALTA. Email: mark.a.camilleri@um.edu.mt AND The Business School, University of Edinburgh, SCOTLAND.
} 


\section{Introduction}

The digital media, including the Internet as well as the social media networks have become indispensable communication tools for online users. Therefore, the organizations are increasingly using them for corporate communication purposes as they facilitate their dialogic and participatory communications with individuals and other organizations (Zerfass, Moreno, Tench, Verčič \& Verhoeven, 2017). Initially, Web 1.0 had improved the organizations’ engagement with their publics. However, the arrival of Web 2.0 has resulted in enhanced interactions between the individuals and the organizations. Web 2.0 enabled the online users to adopt a more active as they could engage with other users through the digital media (as opposed to their passive role in web 1.0). Whilst Web 1.0 was unidirectional and monological, Web 2.0 enabled bidirectional and dialogical communications (Capriotti \& Pardo Kuklinski, 2012; Schivinski \& Dabrowski, 2015). Individuals users could connect with friends, family, colleagues, organizations and interact with them (Newman, Chang, John \& Brian, 2016).

The social networks are a good example of Web 2.0 technologies. The social media have improved the communications between the organizations and their publics. Organizations are using them to engage in two-way communications with their followers on social media (Camilleri, 2018a). It also enables them to evaluate the effectiveness of their communication exchanges as they can track the online users' engagement, in terms of their likes, comments, shares, mentions, etc. (Gregory \& Institute of Public Relations, 1996).

Therefore, this chapter presents a critical review on corporate communication through social networks. It puts forward a conceptual framework that comprises five key dimensions including active presence, interactive attitude, interactive resources, responsiveness, and conversation that are having an impact on dialogical communication in the digital era. Finally, 
this contribution discusses about the implications to the practitioners and suggests future research avenues.

\section{Literature Review}

\section{The dialogic communication of organizations on social networks}

Web 2.0 led organizations to focus their attention on online users. This has generating a change in their communication management, as they have shifted from an informative mainstream approach towards more conversational and dialogic communications models (Capriotti, 2011, 2017). Thus, Web 2.0 is clearly epitomized in social media platforms, that are essentially based on the active participation of their users. These technologies promote interpersonal relations, while facilitating the bidirectional and symmetric communications between organizations and their publics, in the digital environment (Kang \& Sundar, 2016).

The consolidation of the Web 2.0 involved significant changes in the relationship between organizations and their publics. This recent development has resulted in symmetrical interactions and negotiations in terms of clout and communicative power as the online users could engage with the organizations in real time. Hence, the corporate communications have shifted towards a more dialogic or interactive form of communication (Camilleri, 2018a, 2018b; Guillory \& Sundar, 2014; Ingenhoff \& Koelling, 2009; Kent \& Taylor, 1998).

The concept of dialogic communication has been part of the communication and public relations literature for many years (Sommerfeldt \& Yang, 2018). Kent \& Taylor (1998) explained that dialogue involves interpersonal communications. They suggested that it can be carried out online, through the Internet technologies. These authors put forward the principles for effective dialogic communications through the Internet. Their contributions on this topic have triggered the interest of academia and practitioners. They contended that the 
communications and public relations practitioners can utilize digital technologies to establish and keep long term interactions with their stakeholders. Their contribution has addressed a gap in the academic literature as they focused on dialogic communications in the realms of the worldwide web. Even though these principles were developed to research about digital communication on websites, these principles were swiftly adapted to other digital media, including social networks (Chen, Hung-Baesecke \& Chen, 2020; Curtin \& Gaither, 2004; Huang \& Yang, 2015; Muckensturm, 2013; Wang \& Yang, 2020; Waters et al., 2011; Watkins, 2017; Wissen, 2017).

Capriotti and Pardo Kuklinski (2012) defined digital dialogic communication as "an ongoing interaction between organizations and their publics by using Internet tools, which enable information, comments, opinions, assessment and experiences to be exchanged on a continuous basis" (p. 620). Hence, the digital dialogic communication was considered as an important framework to build and nurture relationships with the publics through the Internet technologies (Kent \& Taylor, 2002). The dialogic theory on the Internet entails that organizations should not only disseminate information online, but they are expected to interact and converse with individuals and other publics (Kent, Taylor \& White, 2003; Taylor \& Kent, 2014). Sommerfeldt and Yang (2018) affirmed that "dialogue is foremost concerned with the attitudes held by each party in an interaction" (p.60). Similarly, Kent and Taylor (1998) pointed out that "a dialogic loop allows publics to query organizations and, more importantly, it offers them the opportunity to respond to questions, concerns and problems" (p.323).

\section{Social networks as a key tool for organizational communication}

Safko and Brake (2009) maintained that social networks involve "activities, practices, and behaviors among communities of people who gather online to share information, knowledge, 
and opinions by using conversational media" (p. 6). In a similar vein, Van Zyl (2009) defined social networks "as applications or web sites that support the maintenance of personal relationships, the discovery of potential relationships and should aid in the conversion of potential ties into weak and strong ties, by utilizing emergent Web 2.0 technologies" (p. 909).

Social networks create a new online optimal communication ecosystem for the interactive and dialogic communication of organizations with their publics. This interaction can initiate when organizations send information and/or consult users about their activities through relevant content that is published in their social profiles, or when users communicate their opinions and requirements to organizations (Anderson, Swenson \& Gilkerson, 2016). From the organizational perspective, social networks have changed the interactions between the management and their employees (Wright \& Hinson, 2017). They have also become a key instrument for corporate communications strategies (Carim \& Warwick, 2013; Damásio, Dias \& Andrade, 2012; DiStaso \& McCorkindale, 2013; Iniesta, 2012; Lee, 2016).

The advances in the digital media enable easy access to information and at a great speed. They allow online users, including organizations to interact with other users (including individuals and organizations) in different contexts. For example, the social media can generate enriching experiences to their users. This has encouraged many organizations to use social media networks as communication tools (Linke \& Zerfass, 2012). The growth of interactive technologies, their ease of use, accessibility and popularity represent an opportunity for organizations to foster greater interactions with the different stakeholders (DiStaso, McCorkindale \& Wright, 2011).

Zerfass et al. (2017) noted that the online dimension is top on the list of communication channels. They estimated that social networks will further increase their presence as a communication tool in organizations. The social media platforms are increasingly being used 
by organizations, including businesses to raise awareness about their products or to engage with online users (Camilleri, 2017). Montero (2013) noted that organizations are using Facebook or Twitter to interact with their subscribers (Montero, 2013).

The social networks are an instrument that can be used to improve the organizations' visibility, dialogue, participation in discussions and active listening. Social networks allow their users to create individual profiles, groups or pages. The pages may include links to websites, contact information, location, etc. The social media provide new marketing possibilities to their users as they can reach larger audiences. They can enable them to establish virtual relationships with individuals as well as with the publics. Previous studies confirmed that social networks are being used for promotion and advertising, branding, corporate social responsibility (CSR) communications, dissemination of research findings, and for direct interactions with online users (Camilleri, 2019, 2018b; Cortado \& Chalmeta, 2016; Parveen, Jaafar \& Ainin, 2014). The social networks are a strategic tool for the organizations' dialogic communication and have revolutionized the way how organizations interact with their stakeholders (Chung, Andreev, Benyoucef Duane \& O’Reilly, 2017; Capriotti \& Pardo Kuklinski, 2012).

The organizations are using social media to engage with individuals and the publics. Almost $80 \%$ of Internet users access social networks (Kemp, 2019). Their main motivations to use the digital media are triggered by their social connections, shared identities, pictures, content, social research, social network and status updates, entertainment, social interactions, and information exchanges, among other issues (Avidar, Ariel, Malka \& Levy, 2013; Jung \& Sundar, 2016; Valentini, 2015). This shows that online users have a great interest in creating and sharing content, as well as in interacting on the content that is shared by other users on social networks. Therefore, there is scope for organizations to be present within social networks as it enables them to engage in dialogues with online users (Safko \& Brake, 2009). These organizations are highly exposed to the word-of-mouth publicity and user generated content. It 
is very likely that individuals would actively engage in online conversations through the social networks and/or review sites. Hence, they can share their opinions and insights about their experiences with specific organizations. They may even become influencers as they use social networks to share information about products and/or services with other users.

Various digital platforms, including Trip Advisor, Booking.com and Yelp, among others have incorporated reviews and ratings in their sites. Of course, they need to ensure that their content is accurate, reliable and credible (Camilleri, 2018a; Tench et al., 2017). The online platforms should undertake all reasonable measures to ensure that the individual reviews reflect the real users' opinions and experiences. While it is not always easy to verify the authenticity of user generated content, the digital platforms should have quality control mechanisms and certain processes to ensure that their reviews are clear and truthful for the benefit of the online users who read them.

\section{Evaluation of Social Networks in Corporate Communication}

The organizations ought to evaluate the effectiveness of their corporate communications including their online and interactive messages through social networks. Marca Franc (2011, p.58) insisted that the planning models must include ongoing evaluations of the organizational communications with stakeholders. They should measure whether their corporate communications were successful or not, in terms of achieving their underlying objectives.

The communication management between organizations and their publics on social networks involves the need for tracking and assessing the communication processes. Some studies demonstrate that a consistent use of social networks is key to improve the effectiveness of communication departments (Zerfass, Moreno, Tench, Verčič \& Verhoeven, 2019; Capriotti, 2011). For example, Kent \& Saffer (2014), Linke \& Zerfass (2013) as well as Tench, Moreno, 
Navarro \& Zerfass (2015) suggested that the correct use of social media is very important to better understand and to respond to the consumers' expectations. However, a recent research by Navarro, Moreno \& Al-Sumait (2017) that combined the European Communication Monitor study (ECM) with the Ketchum Leadership Communication Monitor (KLCM), showed that the communication professionals make their decisions (about what content to publish and which activities to carry out on social networks) based on their perceptions, rather than on their analysis of the needs of their publics. So, there is still a gap between the perspectives of communication professionals and the expectations of the publics in terms of the content that organizations should offer and the activities that should be undertaken, in the context of social platforms.

Hence, organizations should regularly assess their dialogic communications' plans. It provides them with an opportunity to reevaluate their digital communication strategies, to identify what communications approaches are being promoted by other organizations on social networks and to determine what is their level of involvement in their online conversations in these platforms. These digital spaces are increasingly being fed with new information from online users. They are publishing their content and engaging in conversations in various social media, in real-time. In recent years, the effectiveness of dialogic communication through social networks has been evaluated through different methodologies and in different organizational contexts. For example, Waters, Canfield, Foster and Hardy (2011) as well as Wang and Yang (2020) have examined the use of Kent and Taylor's dialogic principles of communication on Facebook and Twitter profiles of non-profit and for-profit organizations. Kim, Kim and Nam (2014), as well as Aced-Toledano and Lalueza (2018) have assessed the use of dialogic potential by companies on social media. Romenti, Valentini, Murtarelli and Meggiorin, (2016) have investigated the quality of dialogic conversations among companies and their publics on social media. Auger (2014) analyzed the two-way symmetrical or two-way asymmetrical communication of non- 
profit organizations on Twitter. Park and Kang (2020) and Camilleri (2016) explored the role of dialogic communication of positive CSR behaviors. Moreover, Okazaki, Plangger, West and Menéndez (2019) have studied the potential of strategic CSR communications through Twitter.

These theoretical underpinnings suggest that it is in the organizations' interest to regularly evaluate their digital communication since they can be in a position to review their communication strategies and tactics. This way, they may implement the necessary changes in their communication plans and to identify alternative courses of action (Gregory \& Institute of Public Relations, 1996).

\section{Key dimensions to evaluate dialogic communication on social networks}

The relevant academic literature suggests that there is dialogic communication between the organizations and the online users (e.g. their followers on social media), when both parties are willing to establish a communicational exchange (Kent \& Taylor, 2002; Taylor \& Kent, 2014). This may result in a fruitful dialogue when the organizations respond and engage with the online users on social media platforms. There are two main dimensions that can determine the effectiveness of dialogic communications through social networks: (i) The organizations' "Predisposition to Interaction" and their "Effective Interaction" with the publics. The first one includes three determinants: "Active Presence", "Interactive Attitude" and "Interactive Resources". The second has two determinants: "Responsiveness" and "Conversation" as reported in Figure 3.1. Thus, the researchers have identified five key dimensions that are influencing the effectiveness of dialogic communications through social networks as shown in Figure 1. 
Figure 1: Key dimensions of dialogic communication through social media networks

\begin{tabular}{|c|c|c|c|}
\hline $\begin{array}{l}\text { Presence } \\
\text { Activity }\end{array}$ & Active Presence & \multirow{6}{*}{ Predisposition to } & \multirow{10}{*}{$\begin{array}{c}\text { Dialogic } \\
\text { Communication }\end{array}$} \\
\hline Informational & \multirow{2}{*}{ Interactive Attitude } & & \\
\hline Interactive & & & \\
\hline Graphic Resources & \multirow{3}{*}{ Interactive Resources } & & \\
\hline $\begin{array}{l}\text { Audiovisual } \\
\text { Resources }\end{array}$ & & & \\
\hline $\begin{array}{l}\text { Hypertextual } \\
\text { Resources }\end{array}$ & & & \\
\hline Support & \multirow[t]{2}{*}{ Responsiveness } & \multirow{4}{*}{$\begin{array}{c}\text { Effective } \\
\text { Interaction }\end{array}$} & \\
\hline Virility & & & \\
\hline Intensity & \multirow[t]{2}{*}{ Conversation } & & \\
\hline Reciprocity & & & \\
\hline
\end{tabular}

(Capriotti, Zeller \& Camilleri, 2020)

\section{Predisposition to interact in social networks}

The basis for dialogic communication lies in the subjects' (i.e. the organizations' and the online users') readiness and willingness to interact with one another. A consistent digital presence and an ongoing dialogue with online users via social networks can help organizations to reinforce their stakeholder relationships. The organizations' active presence and their interactive content can facilitate the online users' engagement and may foster two-way conversations (Eberle, 
Berens \& Li, 2013). Their predisposition towards online interactions through social media networks involves three core dimensions: the active presence (that necessitates a continuous online activity that facilitates interaction), the interactive attitude (that manifests the willingness to interact) and the interactive resources (this includes the resources that are used to disseminate content that is intended to promote interaction). Hence, a higher predisposition of organizations towards interaction on social networks is based on a greater level of these three dimensions (active presence, interactive attitude, and interactive resources).

\section{Active presence}

The active presence suggests that maintaining a consistent presence and activity in social networks increases the possibility of generating conversations with users (Bezawada, Rishika, Kumar \& Janakiraman, 2013). The companies can use the social networks as a vehicle to promote their online content including live broadcasts, podcasts, recorded videos, images and stories. It also allows them to create events, conduct surveys and to engage with online users in real-time. Their active presence on social networks enables them to respond and interact with the different publics. The more active their online presence, the higher the likelihood of generating interactive conversations with individuals and organizations. Therefore, a first key dimension is measuring the organizations' active presence, by identifying whether they have an interactive presence in social networks and to determine what is their level of activity.

The 'active presence' analyses the active and consistent use of social networks that enable, facilitate and encourage online users to share the organizations' information with others. Therefore, the organizations' 'active presence' comprises two variables: (a) the level of presence: to determine whether companies have official corporate profiles on social networks;

(b) the level of activity: to analyze the weekly and daily average of publications of 
organizations on the social networks (e.g. posts and updated statuses). A greater active presence would involve a higher predisposition towards interaction.

Several authors agree that social networks are increasingly being incorporated in corporate communication plans as organizations can use these channels to spread content, practice active listening, take part in online conversations, thereby engaging with online users' and building a relationship with them (Bortree \& Seltzer, 2009; Castillo-Esparcia \& Smolak Lozano, 2013; Chu, 2011; Neill \& Moody, 2015; Rodríguez Fernández, 2012; Waters, Burnett, Lamm \& Lucas, 2009). Other authors contend that the organizations' presence on social networks ought to be part of their communication strategy (Losada-Díaz \& Capriotti, 2015; Viñarás Abad \& Cabezuelo Lorenzo, 2012). The practitioners themselves are well aware that there is scope in using social networks in order to enhance their organizations' communications with stakeholders (Wigley \& Zhang, 2011).

Cohen (2015) maintained that it is difficult to quantify the most effective frequency of social media posts. If the organizations post too frequently, they risk annoying their followers, whilst if they post infrequently, their audience may forget that they exist. Various experts, including Capriotti \& Ruesja, 2018; Jordan, 2017; Myers, 2019; Patel, 2016; Shane, 2018; Social Report, 2018; Zeler \& Capriotti, 2017; Zeler, Oliveira \& Malaver, 2019, among others, have put forward their recommendations about the most appropriate publication frequency in different social networks. For example, Kemp (2019) suggested that the posting frequency in Facebook should be between 1 and 2 posts per day, in Twitter between 3 and 5 tweets per day, in YouTube between 1 and 2 videos per week and in Instagram between 1 and 2 posts per day.

Different studies have reported a huge disparity in terms of the outcomes about the presence and activity of organizations on social networks. Some researchers indicated that the activity of organizations on social networks reaches a frequency of less than 1 post per day (Devaney, 
2015; Losada-Díaz \& Capriotti, 2015; Quintly, 2016; Statista, 2017). Conversely, others found that companies are publishing at least one post per day (Estudio de Comunicación, 2017; Kim, Kim \& Hoon Sung, 2014). This disparity in the results is because the researchers may have explored different contexts. Alternatively, they could have used different methodologies and sampling frames to investigate the organizations' activity on social media networks.

\section{Interactive attitude}

The interactive attitude is focused on the need to promote actions and content that can enhance online conversations with online users (Safko \& Brake, 2009). The organizations may encourage their online followers to cocreate content or simply to share their positive experiences with others and to engage in positive word-of-publicity. They are in a position to foster dialogic, two-way communications on social networks in order to build their reputation and trust from their publics (Camilleri, 2015; Camilleri, 2018b). At the same time, they can demonstrate that they care to respond to their stakeholders' queries or concerns.

Therefore, a second key dimension involves measuring the interactive attitude, by examining the organizations' communication approaches on social networks. The organizations' 'interactive attitude' is based on two approaches: (a) informative approach: This refers to the creation and presentation of informative content. Such content is descriptive/expository and encourages unidirectional communications; (b) interactive approach: This refers to the creation and dissemination of content that is intended to trigger conversations and the exchange of information. Hence, interactive approaches facilitate two-way communications (as online users are motivated to participate in online discussions, to disseminate viral content, subscribe to particular activities, share their reviews, opinions and/or recommendations, answer questions, 
etc.). The interactive approaches necessitate that organizations demonstrate a higher predisposition towards interacting with the publics.

Several authors (Bortree \& Seltzer, 2009; Diga \& Kelleher, 2009; Eyrich, Padman \& Sweetser, 2008; Muckensturm, 2013; Wang, 2015) emphasize that social networks promote dialogic communications, which in turn could improve the relationships with stakeholders. Various studies have reported that many organizations are already using the Internet for corporate communication purposes, as they disseminate information about their business with their publics through corporate websites (Kent \& Taylor, 1998; Moreno \& Capriotti, 2006), blogs (Seltzer \& Mitrook, 2007) and social networks (Bortree \& Seltzer, 2009; Ji, Li, North \& Liu, 2016; Pace, Buzzanca \& Fratocchi, 2014; Waters et al., 2009). Their bidirectional communication is possible as long as there are ongoing conversations and a regular dialogue with stakeholders (Valentini, 2015). For this to happen, it is necessary to share relevant content that appeals to the targeted audiences. This way, the corporate communication messages will result in increased stakeholder engagement and may inspire further interactions with the publics (Abitbol \& Lee, 2017).

\section{Interactive Resources}

The interactive resources include those resources that are required to produce relevant, interactive content (Zeler \& Capriotti, 2018, 2019). Theunissen \& Wan Noordin (2012) maintain that successful organizations design appropriate dialogic environments that are intended to facilitate stakeholder engagement. Their corporate communications can be presented through different media including written content and graphics through printed materials, hypertexts and/or audiovisual formats that can be accessed through digital and mobile technologies, etc. Anderson et al. (2016) noted that the communication experts were 
using writing skills to build relationships with their publics. The author argued that the corporate communications content ought to be relevant, concise and easily understood by online users. The organizations' creative messages may include certain keywords that appeal to their followers, to foster their interaction (Abitbol \& Lee, 2017). Hence, online users may be intrigued to engage in conversations through their comments and replies.

Therefore, a third key dimension is to measure the interactive resources, by studying the information resources used by organizations to spread their content on social networks. The 'interactive resources' are a key dimension for corporate communication, as organizations use them to convey information to their publics. Organizations rely on the usage of interactive resources to spread their content to their audiences. The interactive resources, including the social networks can be used to facilitate the interaction and dialogue with online users. The social media enable the exchange of information as they can feature different formats. These formats may usually be combined within the same message. For example, the communication formats include (1) graphic resources: These are composed of fixed images, texts, and emojis. Such resources may be used to foster the dissemination of information in a mono-logic manner; (2) audiovisual resources: These include videos, podcasts and/or animated images (GIFs). Such resources have potential to reach greater audiences because they have a greater capacity to appeal to the individuals' emotions (as they can increase their attention span); (3) hypertextual resources: These comprise links, hashtags and user tags. They include resources that can trigger the exchange of information. Online users may be enticed to participate, interact and engage in online conversations. The greater access, ease of use and availability of hypertextual and audiovisual resources have led many organizations as well as individuals to use these formats and to present them in social networks.

A few studies indicated that there is a significant increase in individuals who are watching videos online and/or via social networks. According to the Global Web Index (2017), more 
than $90 \%$ of Internet users watch online videos every month (Smith, 2017), and more than 50\% watch videos on the main social networks. These findings represent an increase of almost $20 \%$ when compared to the previous year. Valentine (2017) posited that the social media networks have been augmented with the audiovisual resources. The authors argued that the videos add value to the social network strategies as they provide greater levels of engagement. Hence, organizations are encouraged to use the videos to enhance their corporate communication messages (Pletikosa Cvijikj \& Michahelles, 2013).

Currently, we are witnessing an exponential growth in the use of audiovisual resources that are posted on social networks (this may be due to the increase in connection speeds coupled with the technological improvements of the mobile devices). However, a review of the relevant literature reported that the fixed image is still the most used resource among organizations (Twenge, Martin \& Spitzberg, 2019; Luarn, Lin \& Chiu, 2015; Waters et al., 2009). A few studies found that institutional websites were posting more images in social media posts rather than videos and links (Capriotti, Carretón \& Castillo, 2016; McCorkindale, 2010). These findings suggest that organizations are using their available resources to publish visual (graphic) content. Some practitioners were not utilizing other formats including interactive, audiovisual resources, in their corporate communication. These latter resources could improve the organizations' engagement with online users.

\section{Effective communicative exchange in social networks}

The effective communicative exchange involves continuous interactions between the organizations and the online users, and among the online users themselves, within social networks. The successful dialogic exchanges rely on the parties' responsiveness as well as on ongoing conversations (Anderson et al., 2016; Kiousis, 2002; Rafaeli, 1988; Walther, 
Deandrea, Kim \& Anthony, 2010). Thus, the communicational exchange between the organizations and their publics is dependent on various forms of interactive engagement (e.g. likes, comments, follows, tagging, mentions with hashtags, group memberships, etc.). The greater implementation of the conversational exchange will represent a higher level of interaction.

\section{Responsiveness}

The responsiveness is evidenced when the recipients react to the communications that they receive. This is usually demonstrated when there is a response or reply (from the part of the recipient of the information) to an original message. For example, the 'likes' and 'shares' of the social media networks would clearly indicate the online users' responsiveness to the organizational communications (Anderson et al., 2016; Macnamara, 2014). The likes suggest that the individuals are (somehow) appreciating the posted content (within social media), albeit in a passive manner. Recently, Facebook has introduced other features in addition to its popular like function, including love, care, haha, wow, sad and angry emojis. Similarly, Linkedin has included the like, celebrate, love, insightful and curious emojis. Yet, these forms of communication do not involve any verbal expression from the social media users. On the other hand, when individuals share posts (and links) of organizations, or of third parties in their profile, they become volunteer spokesmen for them as they promote their content (Abitbol \& Lee, 2017; Cho, Schweickart \& Haase, 2014). Therefore, a fourth key dimension is to measure Responsiveness, by studying the rate of support and virality generated by organizations on social networks.

Organizations are encouraged to measure their social media users' responsiveness to their digital content that they share via social networks. For instance, individuals may exhibit 
different 'levels of responsiveness' toward the organizations' posts through social media platforms. Their degree of responsiveness may be evaluated by the social media users' engagement, in terms of: 1) Rate of Likes: obtained from the average of total likes by company and post in relation to the number of followers of companies; (2) Rate of Shares: obtained from the total average of shares by company and post in relation to the number of companies' followers. Hence, organizations can use these quantitative measures to better understand the level of responsiveness to their social media activity.

\section{Conversation}

The conversation dimension involves interactive communicative exchanges between two or more parties. The recipients of the communication interact with the communicator and engage in conversations. For example, online users can dialogue and exchange their insights with organizations through the social networks (Anderson et al., 2016; Kiousis, 2002; Walther et al., 2010). The conversation on social networks is usually manifested through 'comments'. The comments are the most genuine expression of the online users' interaction on social networks. They are considered as most relevant element as they provide a rich source of qualitative data to organizations. They require much more commitment than likes and shares, as organizations are expected to respond to the social media users' comments and to engage in direct conversations with them. Hence, online conversations facilitate the communicative exchange between the organizations and the publics (Abitbol \& Lee, 2017; Cho et al., 2014). Therefore, a fifth key dimension analyze the rate of conversation generated by organizations on social networks.

The digital conversations provide qualitative insights to organizations about their followers or other online users. The organizations may capture and analyze the interpretative content of 
online users through social media posts and comments. The quantitative measures may include: a) Intensity: this refers to the total general number of exchanges between an organization and their publics, based on the rate of comments. (b) Reciprocity: this refers to measuring whether there is equitable communication between an organization and its followers, analyzing the level of balance in the exchange between an organization and its publics, obtained from the total percentage of comments made by users and companies. Thus, the more balanced the communicational exchange between an organization and its publics, the greater the quality of the interaction. And the more imbalanced the communicational exchange between an organization and its publics, the poorer the quality of interaction. Thus, it is in the interest of organizations to maintain a balanced communicational exchange with their publics.

\section{Conclusions and Future Research}

The Internet has had an impact on many aspects of organizational structures and processes. It has affected how organizations and stakeholders communicate with one another. The digital media including social media, have provided opportunities and costs for corporate communication. The organizations are encouraged to continuously monitor online conversations and to engage in dialogic communications via social media networks. This way that can nurture relationships with individuals and other organizations. To do so, they need to enhance their predisposition toward social networks and to effectively engage with their users. The dialogic approach of digital communication necessitates that organizations are visible in the social networks through regular posts and updates. They are encouraged to disseminate useful information as well as interactive content that appeals to their followers. Organizations may use written content, images as well as audio visual material, including videos, podcasts, etc., to engage with their publics. Their corporate communication may result in interactive 
engagements and online conversations from the part of the social media users. Thus, it is in organizations' interest to remain vigilant on the content that is being posted on their social media pages and to respond to comments and/or negative word-of-mouth publicity, in timely manner.

The digital media is affecting how organizations engage with their stakeholders (Sommerfeldt \& Yang, 2018). There are several organizations that are very good at managing their dialogic communications through social networks, however there are other laggards that have not embraced these technologies. One of the main reasons for this is that they may lack the slack resources in terms of time as well as dedicated members of staff, to implement effective dialogic communication with their publics (Sommerfeldt, Kent \& Taylor, 2012). Alternatively, they may not have the digital skills and/or language competencies to interact with their followers through the social media networks (Kent \& Saffer, 2014).

This chapter has built on previous theoretical underpinnings relating to corporate communication and digital media. At the same time, it has addressed a gap in the academia as it puts forward a conceptual framework that sheds light on the factors that can affect the successful execution of dialogic communications through social networks. In sum, this contribution posits that there are five key dimensions including 'active presence', 'interactive attitude', 'interactive resources', 'responsiveness', and 'conversation'. It implies that these dimensions ought to be considered by corporate communications practitioners as well as academia. In conclusion, the authors call for further research on the organizations' dialogic communications through the digital media. There is scope to investigate the relationships between the five dimensions that were identified in this contribution. 


\section{References}

Abitbol, A. \& Lee, S. Y. (2017). Messages on CSR-dedicated Facebook pages: What works and what doesn't. Public Relations Review, 43(4), 796-808. https://doi.org/10.1016/j.pubrev.2017.05.002

Aced-Toledano, C. \& Lalueza, F. (2018). Monologues in the conversational era: Assessing the level of dialogic communication that big firms are reaching on social media. El Profesional de La Información, 27(6), 1270. https://doi.org/10.3145/epi.2018.nov.10

Anderson, B. D., Swenson, R. \& Gilkerson, N. D. (2016). Understanding Dialogue and Engagement Through Communication Experts' Use of Interactive Writing to Build Relationships. International Journal of Communication, 10(0), 24. Retrieved from http://ijoc.org/index.php/ijoc/article/view/4569/1759

Avidar, R., Ariel, Y., Malka, V. \& Levy, E. C. (2013). Smartphones and young publics: A new challenge for public relations practice and relationship building. Public Relations Review, 39(5), 603-605. https://doi.org/10.1016/j.pubrev.2013.09.010

Bezawada, R., Rishika, R., Kumar, A. \& Janakiraman, R. (2013). The Effect of Customers ' Social Media Participation on Customer Visit Frequency and Profitability: An Empirical Investigation. Information Systems Research, 24(1), 108-127. https://doi.org/10.1287/isre.1120.0460

Bortree, D. S. \& Seltzer, T. (2009). Dialogic strategies and outcomes: An analysis of environmental advocacy groups' Facebook profiles. Special Section on China Public Relations, 35(3), 317-319. https://doi.org/10.1016/j.pubrev.2009.05.002

Camilleri, M. A. (2015). Valuing stakeholder engagement and sustainability reporting. Corporate Reputation Review, 18(3), 210-222.

Camilleri, M. A. (Ed.). (2016). CSR 2.0 and the new era of corporate citizenship. IGI Global.

Camilleri, M. A. (2017). Unlocking corporate social responsibility through integrated marketing communication. In Camilleri, M.A. (Ed.), Corporate Sustainability, Social Responsibility and Environmental Management (pp. 41-59). Springer, Cham.

Camilleri, M. A. (2018a). The SMEs' technology acceptance of digital media for stakeholder engagement. Journal of Small Business and Enterprise Development, 26(4), 504-521.

Camilleri, M. A. (2018b). Theoretical insights on integrated reporting: The inclusion of nonfinancial capitals in corporate disclosures, Corporate Communications: An International Journal, 23(4), 567-581.

Camilleri, M. A. (2019). Measuring the corporate managers' attitudes towards ISO's social responsibility standard. Total Quality Management and Business Excellence, 30(13-14), 15491561.

Capriotti, P. (2011). Communicating corporate responsibility through the Internet and Social Media. In Ø. Ihlen, J. L. Bartlett \& S. May (Eds.), The Handbook of Communication and Corporate Social Responsibility (pp. 358-378). Boston: Wiley-Blackwell. https://doi.org/10.1002/9781118083246 
Capriotti, P. \& Pardo Kuklinski, H. (2012). Assessing dialogic communication through the Internet in Spanish museums. Public Relations Review, 38(4), 619-626. https://doi.org/10.1016/j.pubrev.2012.05.005

Capriotti, P., Carretón, C. \& Castillo, A. (2016). Testing the level of interactivity of institutional websites: From museums 1.0 to museums 2.0. International Journal of Information Management, 36(1), 97-104. https://doi.org/10.1016/j.ijinfomgt.2015.10.003

Capriotti, P. (2017). The World Wide Web and the Social Media as Tools of CSR Communication. In S. Diehl, M. Karmasin, B. Mueller, R. Terlutter, and F. Weder (Eds.), Handbook of Integrated CSR Communication (Springer). Cham (Suiza).

Capriotti, P. \& Ruesja, L. (2018). How CEOs use Twitter : A comparative analysis of Global and Latin American companies. International Journal of Information Management, 39(September 2017), 242-248. https://doi.org/10.1016/j.ijinfomgt.2018.01.003

Carim, L. \& Warwick, C. (2013). Use of social media for corporate communications by research-funding organisations in the UK. Public Relations Review, 39(5), 521-525. https://doi.org/10.1016/j.pubrev.2013.08.006

Castillo-Esparcia, A. \& Smolak Lozano, E. (2013). Redes sociales y organizaciones. Modelos de evaluación. Ilu, 18(2013), 473-487. https://doi.org/10.5209/rev_HICS.2013.v18.44343

Chen, Y. R. R., Hung-Baesecke, C. J. F. \& Chen, X. (2020). Moving forward the dialogic theory of public relations: Concepts, methods and applications of organization-public dialogue. Public Relations Review, (xxxx), 101878. https://doi.org/10.1016/j.pubrev.2019.101878

Cho, M., Schweickart, T. \& Haase, A. (2014). Public engagement with nonprofit organizations on Facebook. Public Relations Review, 40(3), 565-567. https://doi.org/10.1016/j.pubrev.2014.01.008

Chu, S. (2011). Viral Advertising in Social Media: Participation in Facebook Groups and Responses Among College-Aged Users. Journal of Interactive Advertising, 12(1), 30-43. https://doi.org/10.1080/15252019.2011.10722189

Chung, A. Q. H., Andreev, P., Benyoucef, M., Duane, A. \& O’Reilly, P. (2017). Managing an organisation's social media presence: An empirical stages of growth model. International Journal of Information Management, 37(1), 1405-1417. https://doi.org/10.1016/j.ijinfomgt.2016.10.003

Cohen, D. (2015). REPORT: How Many Posts per Week Should Facebook Pages Average? Adweek. Retrieved 22 May 2017, from http://www.adweek.com/digital/report-locowise-postsper-week-pages/

Cortado, F. J. \& Chalmeta, R. (2016). Use of social networks as a CSR communication tool. $\begin{array}{lllll}\text { Cogent Business and } & 1187783 .\end{array}$ https://doi.org/10.1080/23311975.2016.1187783

Curtin, P. A. \& Gaither, T. K. (2004). International agenda-building in cyberspace: a study of Middle East government English-language websites. Public Relations Review, 30(1), 25-36. https://doi.org/10.1016/j.pubrev.2003.11.003 
Damásio, M. J., Dias, P. \& Andrade, J. G. (2012). The PR Pyramid : Social media and the new role of Public Relations in organizations. Revista Internacional de Relaciones Públicas, 2(4), 11-30. https://doi.org/10.5783/RIRP-4-201201-11-30

Devaney, E. (2015). Social Media Benchmarks Report • 2015. Retrieved from https://cdn2.hubspot.net/hub/53/file-2415418647-pdf/00-OFFERS-HIDDEN/social-mediabenchmarks-2015.pdf?t=1423113374840

Diga, M. \& Kelleher, T. (2009). Social media use, perceptions of decision-making power, and public relations roles. Includes a Special Section: Public Relations in a Time of Economic Crisis, 35(4), 440-442. https://doi.org/10.1016/j.pubrev.2009.07.003

DiStaso, M. W., McCorkindale, T. \& Wright, D. K. (2011). How public relations executives perceive and measure the impact of social media in their organizations. Public Relations Review, 37(3), 325-328. https://doi.org/10.1016/j.pubrev.2011.06.005

DiStaso, M. W. \& McCorkindale, T. (2013). A Benchmark Analysis of the Strategic Use of Social Media for Fortune's Most Admired U.S. Companies on Facebook, Twitter and Youtube. Public Relations Journal, 7(1), 1-33.

Estudio de Comunicación. (2017). Presencia de las empresas del Ibex 35 en el entorno digital. Tercera edición. $\quad$ Retrieved $21 \quad$ February 2017, from http://www.estudiodecomunicacion.com/extranet/portfolio-view/presencia-de-las-empresasdel-ibex35-en-el-entorno-digital/

Eyrich, N., Padman, M. L. \& Sweetser, K. D. (2008). PR practitioners' use of social media tools and communication technology. Public Relations Review, 34(4), 412-414. https://doi.org/10.1016/j.pubrev.2008.09.010

Gregory, A. \& Institute of Public Relations. (1996). Planning and Managing a Public Relations Campaign: A Step- by-Step Guide. London: Kogan Gronstedt.

Guillory, J. E. \& Sundar, S. S. (2014). How Does Web Site Interactivity Affect Our Perceptions of an Organization? Journal of Public Relations Research, 26(1), 44-61. https://doi.org/10.1080/1062726X.2013.795866

Huang, J. \& Yang, A. (2015). Implementing dialogic communication: A survey of IPR, PRSA, and IABC members. Public Relations Review, 41(3), 376-377. https://doi.org/10.1016/j.pubrev.2015.02.003

Ingenhoff, D. \& Koelling, A. M. (2009). The potential of Web sites as a relationship building tool for charitable fundraising NPOs. Public Relations Review, 35(1), 66-73. https://doi.org/10.1016/j.pubrev.2008.09.023

Iniesta, C. R. (2012). El uso de las herramientas digitales por parte de los bancos. El caso de la imagen en Internet de Banco Santander y BBVA en época de crisis. Revista Internacional de Relaciones Públicas, II, 51-72. https://doi.org/10.5783/RIRP-4-2012-03-51-72

Ji, G. Y., Li, C., North, M. \& Liu, J. (2016). Staking reputation on stakeholders: How does stakeholders' Facebook engagement help or ruin a company's reputation? Public Relations Review, 43(1), 201-210. https://doi.org/10.1016/j.pubrev.2016.12.004 
Jordan, R. (2017). How Frequently Should I Post to Facebook? - Rachel B Jordan. Retrieved 21 June 2017, from http://www.rachelbjordan.com/marketing-leadership-blog/howfrequently-should-i-post-to-facebook

Jung, E. H. \& Sundar, S. S. (2016). Senior citizens on Facebook: How do they interact and why? Computers in Human Behavior, 61, 27-35. https://doi.org/10.1016/j.chb.2016.02.080

Kang, H. \& Sundar, S. S. (2016). When Self Is the Source: Effects of Media Customization on Message Processing. Media Psichology, 19(4), 1-28. https://doi.org/10.1080/15213269.2015.1121829

Kemp, S. (2019). Digital 2019: Essential Insights Into How People Around The World Use The Internet, Mobile Devices, Social Media, and E-Commerce. We Are Social and Hootsuite. Retrieved from https://es.slideshare.net/DataReportal/digital-2019-argentina-january-2019v01?from_action=save

Kent, M. L. \& Taylor, M. (1998). Building dialogic relationships through the world wide web. Public Relations Review, 24(3), 321-334. https://doi.org/10.1016/S0363-8111(99)80143-X

Kent, M. L. \& Taylor, M. (2002). Toward a dialogic theory of public relations. Public Relations Review, 28(1), 21-37. https://doi.org/10.1016/S0363-8111(02)00108-X

Kent, M. L., Taylor, M. \& White, W. J. (2003). The relationship between Web site design and organizational responsiveness to stakeholders. Public Relations Review, 29(1), 63-77. https://doi.org/10.1016/S0363-8111(02)00194-7

Kent, M. L. \& Saffer, A. J. (2014). A Delphi study of the future of new technology research in public relations. Public Relations Review, 40(3), 568-576. https://doi.org/10.1016/j.pubrev.2014.02.008

Kim, D., Kim, J. H. \& Nam, Y. (2014). How does industry use social networking sites? An analysis of corporate dialogic uses of Facebook, Twitter, YouTube, and LinkedIn by industry type. Quality and Quantity, 48(5), 2605-2614. https://doi.org/10.1007/s11135-013-9910-9

Kim, S., Kim, S.-Y. \& Hoon Sung, K. (2014). Fortune 100 companies ' Facebook strategies: corporate ability versus social responsibility. Journal of Communication Management, 18(4), 343-362. https://doi.org/10.1108/JCOM-01-2012-0006

Kiousis, S. (2002). Interactivity: A concept explication. New Media and Society, 4(3), 355383. https://doi.org/10.1177/146144480200400303

Lee, S. (2016). How can companies succeed in forming CSR reputation? Corporate Communications: An International Journal, 21(4), 435-449. https://doi.org/10.1108/CCIJ-012016-0009

Linke, A. \& Zerfass, A. (2012). Future trends in social media use for strategic organisation communication: Results of a Delphi study. Public Communication Review, 2(2), 17-29. Retrieved from https://epress.lib.uts.edu.au/journals/index.php/pcr/article/viewFile/2736/3026

Linke, A. \& Zerfass, A. (2013). Social media governance: Regulatory frameworks for successful online communications. Journal of Communication Management, 17(3), 270-286. https://doi.org/10.1108/JCOM-09-2011-0050 
Losada-Díaz, J. C. \& Capriotti, P. (2015). La comunicación de los museos de arte en Facebook: comparación entre las principales instituciones internacionales y españolas. Palabra Clave, 18(3), 889-904. https://doi.org/10.5294/pacla.2015.18.3.11

Luarn, P., Lin, Y.-F. \& Chiu, Y.-P. (2015). Influence of Facebook brand-page posts on online engagement. Online Information Review, 39(4), 505-519. https://doi.org/10.1108/OIR-012015-0029

Macnamara, J. (2014). Emerging international standards for measurement and evaluation of public relations: A critical analysis. Public Relations Inquiry, 3(1), 7-29. https://doi.org/10.1177/2046147X14521199

Marca Franc, G. (2011). La evaluación de los modelos de planificación estratégica de las Relaciones Públicas. Análisis comparativo del uso de la evaluación de la comunicación en las redes hospitalarias de los modelos sanitarios de España, el Reino Unido y Estados. Tesis doctoral. Universitat Rovira i Virgili.

McCorkindale, T. (2010). Can you see the writing on my wall? A content analysis of the Fortune 50's Facebook social networking sites. Public Relations Journal, 4(3), 1-14. https://doi.org/10.1017/CBO9781107415324.004

Montero, L. (2013). Reflexiones sobre la investigación en redes sociales: Facebook y Twitter. In I Congreso Internacional de Comunicación y Sociedad Digital (p. 11). Logroño: UNIR. Retrieved from https://dialnet.unirioja.es/descarga/articulo/4565937.pdf\%5Cnhttps://dialnet.unirioja.es/servle t/extart?codigo $=4565937$

Moreno, A. \& Capriotti, P. (2006). La comunicación de las empresas españolas en sus webs corporativas. Análisis de la información de responsabilidad social, ciudadanía corporativa y desarrollo sostenible. Zer - Revista de Estudios de Comunicación, 11(21), 49-64. Retrieved from http://www.ehu.eus/zer/hemeroteca/pdfs/zer21-04-moreno.pdf

Moreno, A., Molleda, J. C., Álvarez Nobell, A., Herrera, M. V., Athaydes, A. \& Suárez, A. M. (2019). Comunicación estratégica y sus retos: fake news, confianza, información para la toma de decisiones, liderazgo y compromiso laboral. Resultados de una encuesta en 19 países. Bruselas and Madrid. Retrieved from www.latincommunicationmonitor.com

Muckensturm, E. (2013). Using Dialogic Principles on Facebook: How the Accommodation Sector Is Communicating With Its ' Consumers. Clemson University. Retrieved from http://tigerprints.clemson.edu/cgi/viewcontent.cgi?article=2657andcontext=all_thesesandseiredir=1 andreferer=http://scholar.google.com/scholar?start=10andq=Is+Facebook + used + by $+b$ ed+and+breakfastsandhl=enandas_sdt $=0,5 \#$ search $=\% 22$ Facebook used by bed breakfasts $\% 22$

Myers, L. (2019). How Often To Post On Social Media: 2019 Success Guide. Retrieved 15 May 2019, from https://louisem.com/144557/often-post-social-media

Navarro, C., Moreno, Á. \& Al-Sumait, F. (2017). Social media expectations between public relations professionals and their stakeholders: Results of the ComGap study in Spain. Public Relations Review, 43(4), 700-708. https://doi.org/10.1016/j.pubrev.2016.12.008 
Neill, M. S. \& Moody, M. (2015). Who is responsible for what? Examining strategic roles in social media management. Public Relations Review, 41(1), 109-118. https://doi.org/10.1016/j.pubrev.2014.10.014

Newman, R., Chang, V., John, R. \& Brian, G. (2016). International Journal of Information Management Web 2.0 - The past and the future. International Journal of Information Management, 36(4), 591-598. https://doi.org/10.1016/j.ijinfomgt.2016.03.010

Okazaki, S., Plangger, K., West, D. \& Menéndez, H. D. (2019). Exploring digital corporate social responsibility communications on Twitter. Journal of Business Research, (September), 1-8. https://doi.org/10.1016/j.jbusres.2019.09.006

Pace, S., Buzzanca, S. \& Fratocchi, L. (2014). The structure of conversations on social networks: Between dialogic and dialectic threads. International Journal of Information Management, 36(6), 1144-1151. https://doi.org/10.1016/j.ijinfomgt.2016.04.001

Park, Y. E.\& Kang, M. (2020). When crowdsourcing in CSR leads to dialogic communication: The effects of trust and distrust. Public Relations Review, (September 2018), 101-867. https://doi.org/10.1016/j.pubrev.2019.101867

Parveen, F., Jaafar, N. I. \& Ainin, S. (2014). Social media usage and organizational performance: Reflections of Malaysian social media managers. Telematics and Informatics, 32(1), 67-78. https://doi.org/10.1016/j.tele.2014.03.001

Patel, N. (2016). How Frequently You Should Post on Social Media According to the Pros. Retrieved 21 June 2017, from https://www.forbes.com/sites/neilpatel/2016/09/12/howfrequently-you-should-post-on-social-media-according-to-the-pros/\#4356de7e240f

Pletikosa Cvijikj, I. \& Michahelles, F. (2013). Online engagement factors on Facebook brand pages. Social Network Analysis and Mining, 3(4), 843-861. https://doi.org/10.1007/s13278013-0098-8

Quintly. (2016). Brand Study H1 2016: How do 30 of the biggest brands use Facebook? Retrieved from https://www.quintly.com/blog/2016/10/30-biggest-brands-on-facebookanalyzed-in-depth/

Rafaeli, S. (1988). Interactivity: From new media to communication. In Sage Annual Review of Communication Research: Advancing Communication Science (Vol. 16, pp. 111-134). Retrieved from http://scholar.google.com/scholar?hl=enandbtnG=Searchandq=intitle:Interactivity:+From+Ne w+Media+to+Communication\#0\%5Cnfile:///Users/Home/Dropbox/Masters

Thesis/Articles/Interactivity/Rafeili_?.Interactivity.pdf

Rodríguez Fernández, Ó. (2012). Facebook. Aplicaciones profesionales y de empresa. (A. Multimedia, Ed.). Madrid: Anaya Multimedia.

Romenti, S., Valentini, C., Murtarelli, G. \& Meggiorin, K. (2016). Measuring online dialogic conversations' quality: a scale development. Journal of Communication Management, 20(4), 328-346. https://doi.org/10.1108/JCOM-11-2015-0090

Safko, L. \& Brake, D. K. (2009). The Social media bible: tactics, tools, and strategies for business success. New Jersey: Wiley. 
Schivinski, B. \& Dabrowski, D. (2015). The impact of brand communication on brand equity through Facebook. Journal of Research in Interactive Marketing, 9(1), 31-53. https://doi.org/10.1108/JRIM-02-2014-0007

Seltzer, T. \& Mitrook, M. A. (2007). The dialogic potential of weblogs in relationship building. Public Relations Review, 33(2), 227-229. https://doi.org/10.1016/j.pubrev.2007.02.011

Shane, D. (2018). How Often You Should Post on Social Media, According to 10 Studies. Retrieved 10 May 2019, from https://www.inc.com/dakota-shane/how-often-you-should-poston-social-media-according-to-10-studies.html

Smith, T. (2017). Global Web Index Trends 17: The Trends to Watch in 2017. Retrieved 10 October 2017, from https://cdn2.hubspot.net/hubfs/304927/Downloads/Trends-17.pdf

Social Report. (2018). How Often Should You Post On Social Media? Retrieved 10 May 2019, from https://es.socialreport.com/insights/article/115003574046-How-Often-Should-YouPost-On-Social-Media-

Sommerfeldt, E., Kent, M. L. \& Taylor, M. (2012). Activist practitioner perspectives of website public relations: Why aren't activist websites fulfilling the dialogic promise? Strategically Managing International Communication in the 21st Century, 38(2), 303-312. https://doi.org/10.1016/j.pubrev.2012.01.001

Sommerfeldt, E. J. \& Yang, A. (2018). Notes on a dialogue: twenty years of digital dialogic communication research in public relations. Journal of Public Relations Research, 30(3), 5964. https://doi.org/10.1080/1062726X.2018.1498248

Statista. (2017). Average number of weekly posts on social media in the U.S. 2015. Retrieved 15 May 2017, from https://www.statista.com/statistics/620974/average-number-brand-postssocial-media/

Taylor, M. \& Kent, M. L. (2014). Dialogic Engagement: Clarifying Foundational Concepts. Journal of Public Relations Research, 26(5), 384-398. https://doi.org/10.1080/1062726X.2014.956106

Tench, R., Moreno, A., Navarro, C. \& Zerfass, A. (2015). Does social media usage matter? How communicators perceive and practice digital communications. Public Relations Review, 41, 242-253. https://doi.org/10.1016/j.pubrev.2014.12.006

Tench, R., Verčič, D., Zerfass, A., Moreno, Á. \& Verhoeven, P. (2017). Mediatised: Media All Around Us. In Communication Excellence: How to Develop, Manage and Lead Exceptional Communications (pp. 19-42). Palgrave Macmillan. https://doi.org/10.1007/978-3-319-488608

Theunissen, P. \& Wan Noordin, W. N. (2012). Revisiting the concept 'dialogue' in public relations. Public Relations Review, 38(1), 5-13. https://doi.org/10.1016/j.pubrev.2011.09.006

Twenge, J. M., Martin, G. N. \& Spitzberg, B. H. (2019). Trends in US Adolescents' media use, 1976-2016: The rise of digital media, the decline of TV, and the (near) demise of print. Psychology of Popular Media Culture, 8(4), 329-345. 
Valentine, O. (2017). Over 1 in 2 Now Watch Video on Social Each Month - GlobalWebIndex Blog. Retrieved 19 October 2017, from http://blog.globalwebindex.net/chart-of-the-day/1-2now-watch-video-social-month/

Valentini, C. (2015). Is using social media 'good' for the public relations profession? A critical reflection. Public Relations Review, 41(2), 170-177. https://doi.org/10.1016/j.pubrev.2014.11.009

Van Zyl, A. S. (2009). The impact of Social Networking 2.0 on organisations. Electronic Library, 27(6), 906-918. https://doi.org/10.1108/02640470911004020

Viñarás Abad, M. \& Cabezuelo Lorenzo, F. (2012). Claves para la participación y generación de contenido en las redes sociales: estudio de caso del Museo del Prado en Facebook . AdComunica. Revista Científica de Estrategias, Tendencias e Innovación En Comunicación, 3, 87-103. https://doi.org/10.6035/2174-0992.2012.3.6

Walther, J. B., Deandrea, D., Kim, J. \& Anthony, J. C. (2010). The Influence of Online Comments on Perceptions of Antimarijuana Public Service Announcements on YouTube. Human Communication Research, 36(4), 469-492. https://doi.org/10.1111/j.14682958.2010.01384.x

Wang, Y. (2015). Incorporating Social Media in Public Relations : A Synthesis of Social Media-Related Public Relations Research. Public Relations Journal, 9(2007), 1-14.

Wang, Y. \& Yang, Y. (2020). Dialogic communication on social media: How organizations use Twitter to build dialogic relationships with their publics. Computers in Human Behavior, 104(September 2019), 106-183. https://doi.org/10.1016/j.chb.2019.106183

Waters, R. D., Burnett, E., Lamm, A. \& Lucas, J. (2009). Engaging stakeholders through social networking: How nonprofit organizations are using Facebook. Public Relations Review, 35(2), 102-106. https://doi.org/10.1016/j.pubrev.2009.01.006

Waters, R. D., Canfield, R. R., Foster, J. M. \& Hardy, E. E. (2011). Applying the dialogic theory to social networking sites: Examining how university health centers convey health messages on Facebook. Journal of Social Marketing, 1(3), 211-227. https://doi.org/10.1108/20426761111170713

Watkins, B. A. (2017). Experimenting with dialogue on Twitter: An examination of the influence of the dialogic principles on engagement, interaction, and attitude. Public Relations Review, 43(1), 163-171. https://doi.org/10.1016/j.pubrev.2016.07.002

Wigley, S. \& Zhang, W. (2011). A Study of PR Practitioners' Use of Social Media in Crisis Planning. Public Relations Journal, 5(3), 1-16.

Wissen, N. Van. (2017). Building Stakeholder Relations Online: How Nonprofit Organizations Use Dialogic and Relational Maintenance Strategies on Facebook. Communication Management Review, 2(April), 54-74. https://doi.org/10.22522/cmr20170119

Wright, D. K. \& Hinson, M. (2017). Tracking How Social and Other Digital Media are Being Used in Public Relations Practice: A Twelve-Year Study. Public Relations Journal, 11(1). 
Retrieved from https://prjournal.instituteforpr.org/wp-content/uploads/PRJ-2017-WrightHinson-2-1.pdf

Zeler, I. \& Capriotti, P. (2017). Facebook como herramienta de Relaciones Públicas en las empresas: Información de negocios y de RSE en las empresas con mejor reputación a nivel mundial. Revista Internacional de Relaciones Públicas, VII(14), 145-164. https://doi.org/10.5783/RIRP-14-2017-09-145-164

Zeler, I. \& Capriotti, P. (2018). Gestión interactiva de la comunicación de la RSE de las empresas de Argentina en Facebook. Retos, 8(16), 7-18. https://doi.org/10.17163/ret.n16.2018.01

Zeler, I. \& Capriotti, P. (2019). Communicating corporate social responsibility issues on Facebook's corporate fanpages of Latin American companies. El Profesional de La Información, 28(5), 1-9. https://doi.org/10.3145/epi.2019.sep.07

Zeler, I; Oliveira, A. Y Malaver, S. (2019). La gestión comunicativa de las empresas vitivinícolas de España en las principales redes sociales. Revista Internacional de Relaciones Públicas, Vol. IX, No 18, 161-178. http://dx.doi.org/10.5783/RIRP-18-2019-09-161-178.

Zerfass, A., Moreno, Á., Tench, R., Verčič, D. \& Verhoeven, P. (2017). European Communication Monitor 2017. How strategic communication deals with the challenges of visualisation, social bots and hypermodernity. Results of a survey in 50 countries. Brussels: EACD/EUPRERA, Quadriga Media Berlin. Retrieved from www.communicationmonitor.eu

Zerfass, A., Verčič, D., Verhoeven, P., Moreno, A. \& Tench, R. (2019). European Communication Monitor 2019. Exploring trust in the profession, transparency, artificial intelligence and new content strategies. Results of a survey in 46 countries. Brussels. Retrieved from www.europeancommunicationmonitor.com 